\title{
OPEN-AIR MUSEUM: A RETHINKING FOR INDONESIAN PARADIGM (AN OVERVIEW TOWARDS OPEN-AIR VERNACULAR HOUSES MUSEUMS IN AUSTRIA)
}

\author{
Yusfan Adeputera Yusran \\ Department of Architecture, Universitas Brawijaya, \\ Jl. MT. Haryono 167, Malang 65145, INDONESIA \\ Email: yusfan@ub.ac.id
}

\begin{abstract}
Undisputedly, globalization has changed the human beings. Unexceptionally the way we live. The value of tradition is slowly fading, replaced by modern lifestyles with all its pragmatism. Traditional houses are also abandoned gradually, changed by contemporary modern houses. Then, where these traditional houses should be? Fortunately for the locals who are still committed to consistently withstand with their traditions. In contrast to other deteriorated cultural peoples, which most of them are no longer willing to dwell their inherited houses. Here, open-air museum arose to be reconsidered. Behind its controversy, open-air museum has been an answer to the phenomenon of conservation in Europe. In the midst of the controversy over the value of the place, open-air museum become a solution for European when their traditional houses increasingly burdensome in terms of maintenance. This paper aims to give an image of how Austrians preserve their traditional/vernacular houses. Six biggest open-air vernacular/traditional houses museums that dispersed on characterizedcultural region over Austria will be described comparatively here in order to give a description about the prospect for Indonesia. There are numerous principles that could be considered as guidelines, both as a theoretical framework and technical issues. Resulted recommendation could be used as hints in conserving Indonesian traditional houses in a different perspective.
\end{abstract}

Keywords: Open-air museum; vernacular/traditional houses; conservation.

\section{INTRODUCTION}

The importance of ex situ conservation activities in the form of open-air museum (OAM) is often cited as a significant benefit in sustaining culture, in this case, vernacular houses, for future generation. Many perceptions arose towards this treatment, both positive (Rentzhog, 2007) and negative thoughts (Shafernich, 1994). Kempers stated, "The best to keep these traditional houses in its original site, but if there is no possibility to keep it, removal to the new site is to be preferred" (Kempers, 1971).

Indonesia with hundreds of ethnic spread across tens of thousands of islands faces many obstacles in preserving their custom traditional houses. Fortunately for the locals that are still committed to consistently preserve their tradition as in Waerebo or Ratenggaro. They still stand straight by their cultural tenets, as embodied at their houses. In contrast to the Toraja now, which most of them are no longer willing to dwell their inherited Tongkonan. Or the Karo, which are reluctant to inhabit their Siwaluh jabu anymore, and prefer to live in a modern brick house next door, and other obvious phenomena that evince traditionalism is outdated and no longer seen as satiating thing. Here, open-air museum arose to be reconsidered.
Although the first, the presence of TMII yet capable of being a national pride, even bolster the image of falsehood hiding behind the slogan of preservation (Hitchcock, 2005; Kerlogue, 2008). Auspiciously, vigorous conservation efforts have been carried out today by various foundations, even though still have not been able to save all the endangered houses that race against time (Yusran, 2016a). Although late, the government also has started to pay attention, despite still constrained by rules and bureaucracy (Direktorat Pelestarian Cagar Budaya dan Permuseuman, Kementerian Pendidikan dan Kebudayaan Republik Indonesia, 2015). Government (especially the local) is also aware of the lack of attention to the museum, especially in management systems and making attractive atmospheres. Need a new formula that can drive hand in hand both in conserving and entertaining.

If envisaged, technically, effort in conserving traditional houses of Indonesia is constrained by distance and location. Infrastructure and so forth are obviously mounded. Beyond that all, costly issues would be a major challenge over all. Thus, it is important to consider some hints that could be as trigger why Indonesian needs to reconsider open-air museum, as the alternative option for those remains traditional house to be kept salvaged. 


\section{LITERATURE REVIEW}

Europe has proven successful saves its traditional houses by housed it as open-air museum (OAM). Formerly, many people (mostly archaeologist) were skeptical in the terms of rooted-culture, but now paradoxically, very much 'in' (Kempers, 1971). Costly maintenance becomes the key reason for most owners. Besides that, the inevitability of modern way of life insists them to live modernly. Willy-nilly, futureness certainly erodes the value of the locality, including the traditional way (house) of life. Thus, OAM arouses as a tangible response to save what we can still see and feel today.

OAM in Europe was drafted since 1799 and just then implemented in 1891 by Arthur Hazelius marked by the founding of Skansen in Stockholm. Conditions of society, which more modernized by the revolution, and the impact of war devastated their homes and way of life, making the desire to recreate their past strengthen (Rentzhog, 2007). Currently, Skansen became a pioneer and patron of the hundreds of similar museums around the world.

Association of European Open Air Museum $(\mathrm{AEOM})$ as an affiliated organization of the International Council of Museums (ICOM), defines OAM as "scientific collections in the open air of various types of structures, which as constructional and functional entities, illustrate settlement patterns, dwellings, economy and technology". Furthermore, AEOM has admitting OAM should present its collection as 1:1 three-dimensional scale, as the result of reconstruction/rehabilitation/removal of rural (vernacular) buildings or relics. Though in recent years, the requirement extended to any cultural heritage.

OAM itself in Europe is very diverse. These diversities came along according cultures, the traditions, architectural feature and the history of a specific region or country. For example, Austria as one of the developed countries in Europe with characterized farming culture has been proven able to save many of their traditional peasant houses. Coupled, there are still many peoples who still found living in those kinds of houses in rural area of Austria nowadays. For preservation aim, from field survey, identified 6 places where they laid spacious museums to preserve their traditional houses exsitucally, that is in: Stübing, Niedersulz, Maria Saal, Gerersdorf, Grossgmain, and Kramsach.

\section{Stübing Freilichtmuseum}

Stübing Freilichtmuseum (Freilichtmuseum means Open-air museum) is one of the 10 largest and most impressive open-air museums in Europe, and
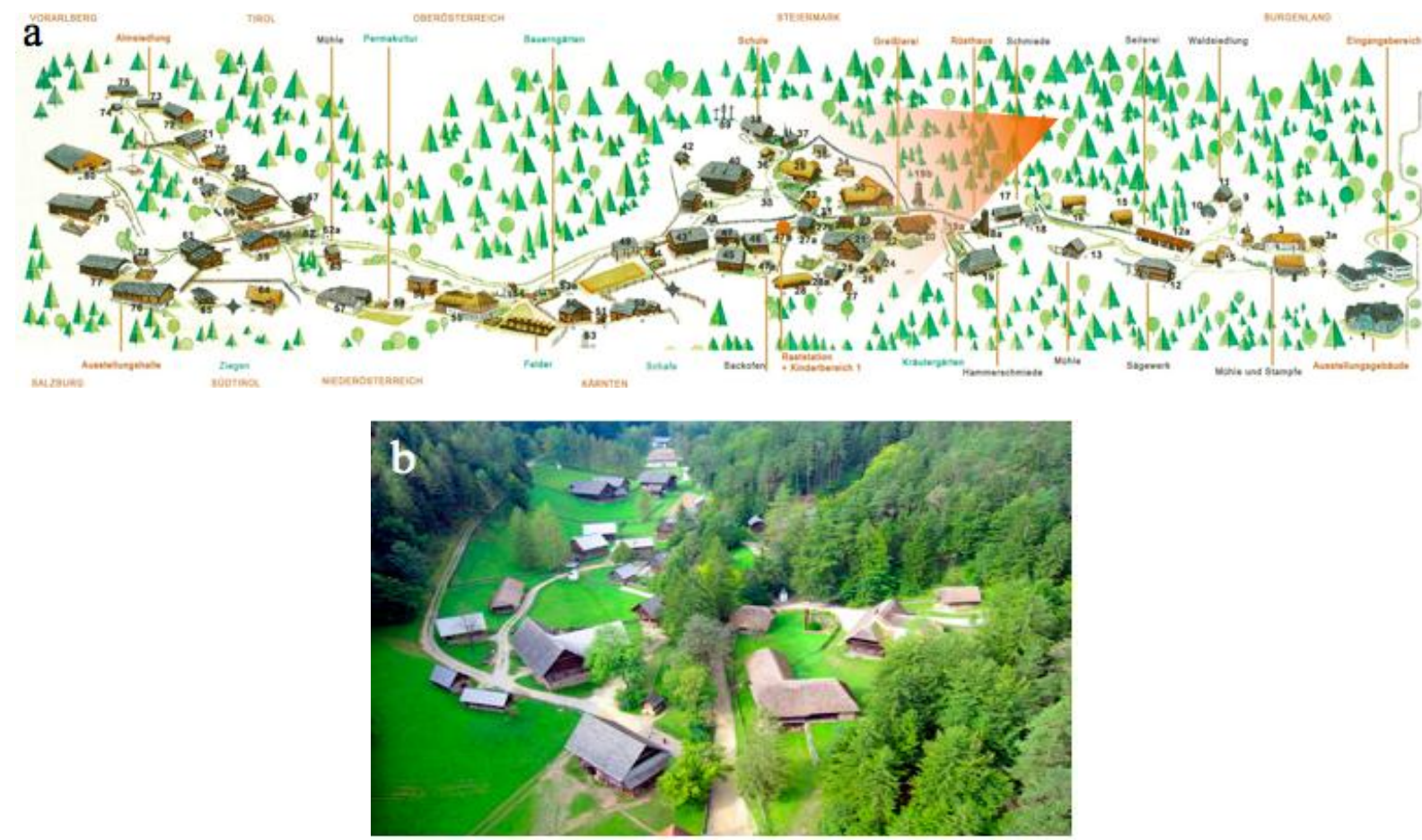

Fig. 1. (a) Stübing Frelichtmuseum Map (Stübing frelichtmuseum website, 2015); (b) Aerial view of Stübing Frelichtmuseum (Reinhart Nunner, 2012) 
also has gained reputation as a national treasure of Austria since its establishment in 1962. Located 15 $\mathrm{km}$ north of Graz, the museum covers 65 hectares of land, all for displaying 97 historical buildings from 8 states in Austria, such as wooden homesteads, granaries and kilns, showing different styles of construction in various parts of the country over the last six centuries (see fig. 1) and makes it as the one and only open-air museum of Austria presenting a survey of traditional culture of all Austrian states. On 1985 it was transformed into a foundation of public right, which has to serve scientific investigation and documentation of vernacular architecture and rural life, how did people build, live and work in the rural regions of Austria. Being one of the largest central museums of its kind in Europe Stübing was awarded the museum quality stamp of the International Council of Museums (ICOM) of UNESCO.

In Stübing, conservation was done by moving uninhabited traditional houses from several areas in Austria to be rebuilt in this place. These buildings mostly relocated due to the inability of the previous owner's in maintaining. Some buildings in Stübing were translocated completely, while the other was built with a few adjustments, as adjusted to the contours of the new place and replacing the weathered rotten material. There are also some new buildings constructed based on historical documents by using indigenous material that's similar to its origin.

\section{Niedersulz Museumsdorf}

Museumsdorf Niedersulz is an open-air museum in Austria that displays traditional buildings and architecture from the Weinviertel (Austria's largest wine growing area). Located in the village of Sulz im Weinviertel, about $45 \mathrm{~km}$ north of Vienna in the state of Lower Austria (Niederösterreich). The VillageMuseum of Niedersulz is the largest open-air museum in Lower Austria and was founded in 1979. It consists of 80 historical buildings in the area of $22 \mathrm{Ha}$ (see fig. 2).

This Village-museum is laid out in the form of a row-grid village, portrays a traditional form of settlement set along at characterized-lowland of wineries which stream going back to 1000 AD. Mostly, the houses are rectangular-shaped, usually consist of an adobe housing unit, a stable, a shed and an out-building which also delineates the backside of the property. In here, wooden buildings like Städel (barn) were translocated completely as a whole. While for adobe buildings, only the transportable parts such as trusses, wooden ceilings, windows, doors, floorboards were taken over and reassembled to the new constructed buildings at the museum's site.
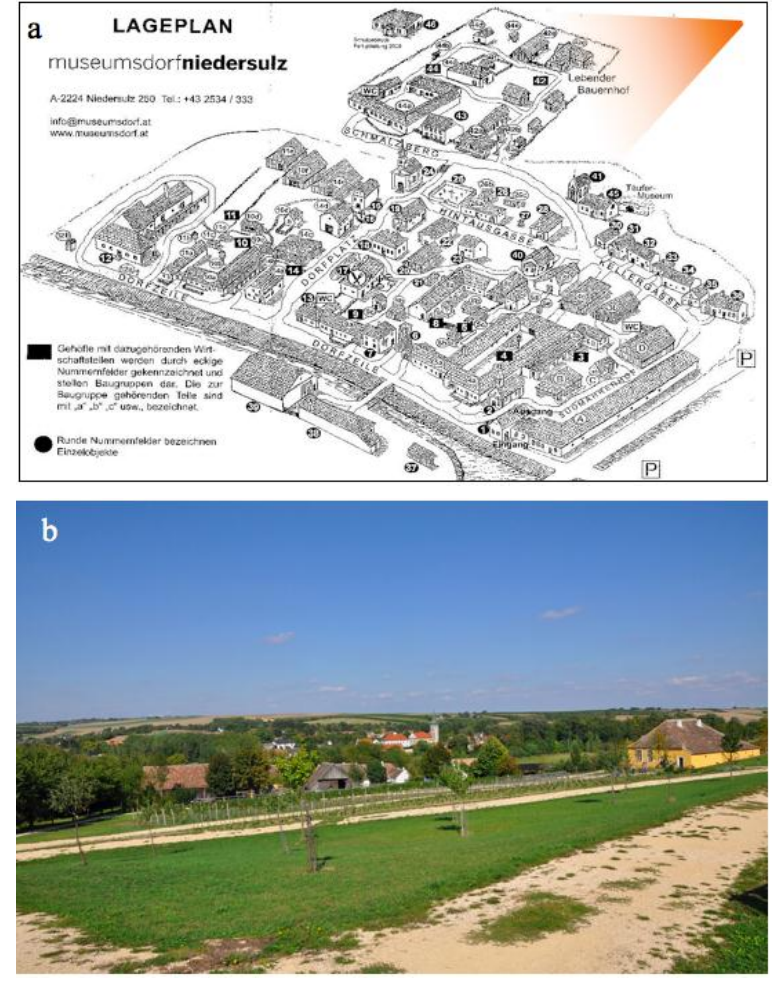

Fig. 2. (a) Niedersulz Museumdorf Map (Niedersulz museumdorf, 2015); (b) Scenery of Niedersulz Museumdorf (Yusfan, 2015)

\section{Salzburger Großgmain Freilichtmuseum}

Located in the foothills of mount Untersberg, about $12 \mathrm{~km}$ to the southwest of Salzburg city, the 50 ha museum grounds is settled in a landscape of conservation area and nature reserve. The setting of the buildings is designed according to the historical regions of the Salzburg state as which have been grouped as Flachgau, Tennengau, Pongau, Pinzgau and Lungau (see fig. 3). This zoning is connected by 7 $\mathrm{km}$ long network of hiking trails and connects over 100 buildings. The heritage railway follows a $1.7 \mathrm{~km}$ long track passing through large parts of the area. Additional attractions such as several permanent exhibitions, a hydrotherapy area, an interactive butterfly-watching trail and demonstrations of old handicrafts enrich the broad array of historic farming culture in this open-air museum.

\section{Tiroler Bauernhöfe Kramsach Freilichtmuseum}

The Museum Tirolel Bauernhöfe, which was founded in 1974, is located in a municipality of Kramsach in the Kufstein district, $52 \mathrm{~km}$ in the northeast of Innsbruck city. This museum, which is commonly known as Kramsach Freilichtmuseum, gives a fascinating insight into the Tyrolean past with its preserved 37 historic buildings in the $8 \mathrm{Ha}$ area of hilly site with magnificent mountain scenery of Alps 
mountain (see fig. 4). In here, visitors will experience the lifestyle and economy of the peasant population of Tyrol in the past rural era.
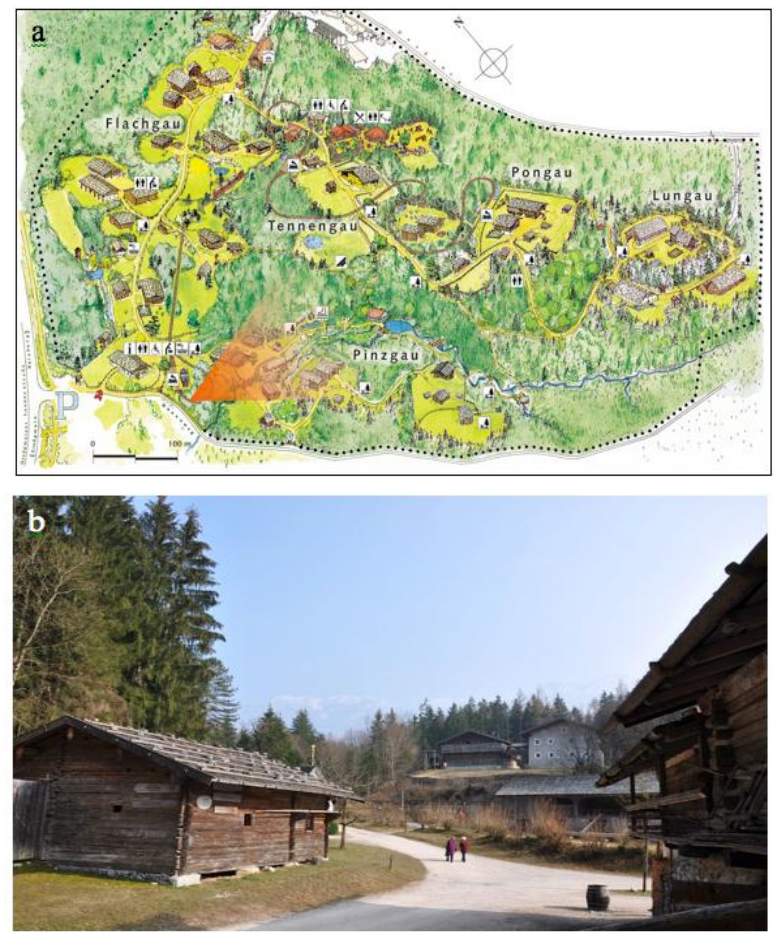

Fig. 3. (a) Salzburger Großgmain Freilichtmuseum Map (Salzburger Großgmain Freilichtmuseum website, 2016); (b) Houses Collection in Salzburger Museumdorf (Yusfan, 2016)
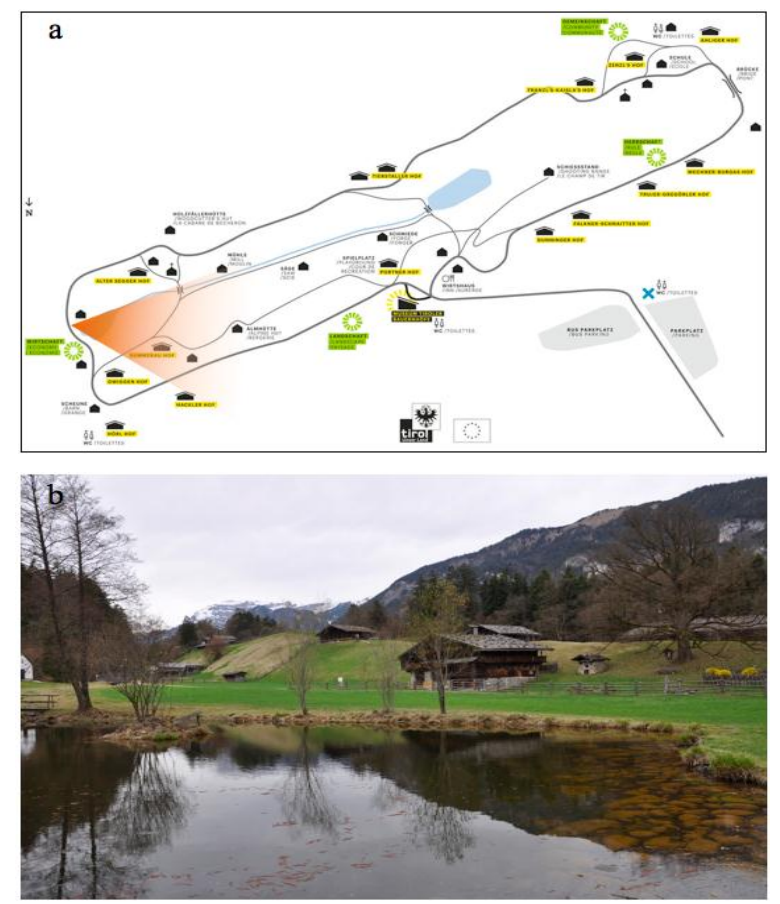

Fig. 4. (a) Tiroler Bauernhöfe Kramsach Freilichtmuseum Map (Tiroler Freilichtmuseum website, 2016); (b) Houses Arranged in Tiroler Bauernhöfe Kramsach Freilichtmuseum (Yusfan, 2016)

\section{Maria Saal Freilichtmuseum}

The Freilichtmuseum Maria Saal is located in Maria Saal, $9 \mathrm{~km}$ on the north of Klagenfurt city. 38 objects of peasant houses and farmhouse types from different regions of Carinthia are exhibited here, makes this museum as the biggest open-air museum in Carinthia state and provides the visitors an experience with the different ways of life of the individual regions of Carinthia. The 3,5 ha site breaks down into four terraces, which is characterizing rural settlement of Carinthia (see fig. 5). Founded in 1972, besides the farmhouses, visitors also could experience the peasant trade in life called "industrial site", such as Flodermühlen, sawmills, charcoal, and limekiln.
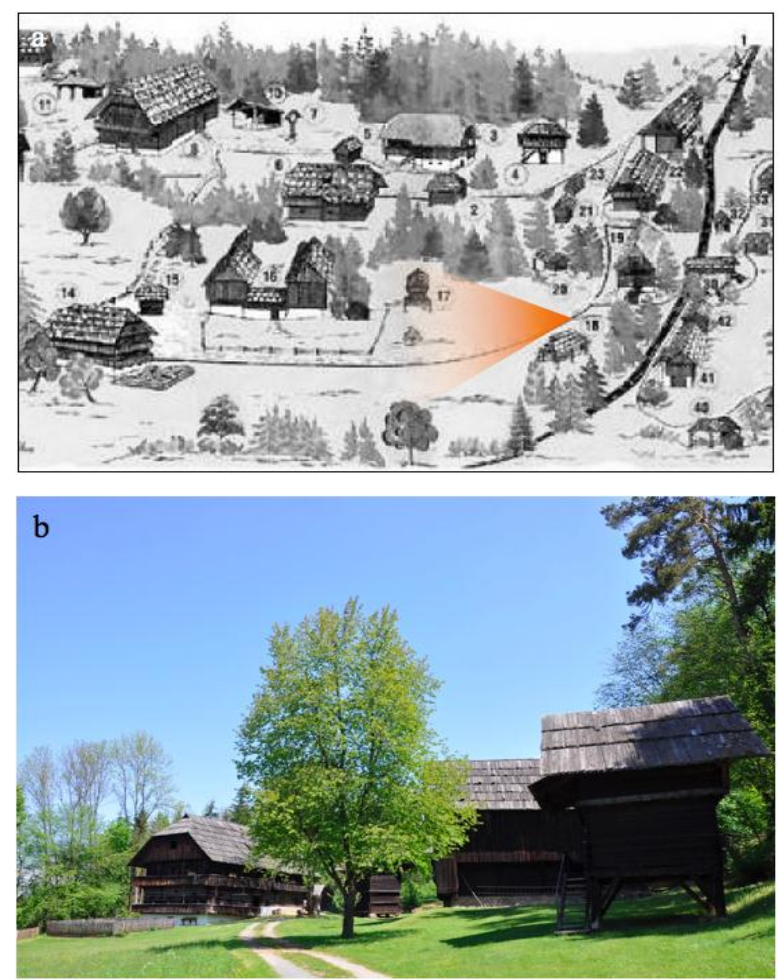

Fig. 5. (a) Maria Saal Freilichtmuseum Map (Maria Saal Freilichtmuseum website, 2016); (b) Maria Saal Freilichtmuseum site (Yusfan, 2016)

\section{Gerersdorf Ensemble Freilichtmuseum}

In the lowland landscape of Southern Burgenland, $8 \mathrm{~km}$ in the western of Güssing, settled Gerersdorf Ensemble Freilichtmuseum as one of the attractive destination in Burgenland state. Here, established 32 houses in the $2 \mathrm{Ha}$ area of the site, which mostly represents farm housing, mixed with reconstructed-modern buildings, home to a wealth of native commodities and agricultural implements that provide a comprehensive insight into the Pannonian culture of the 18th and 19th centuries (see fig. 6). 

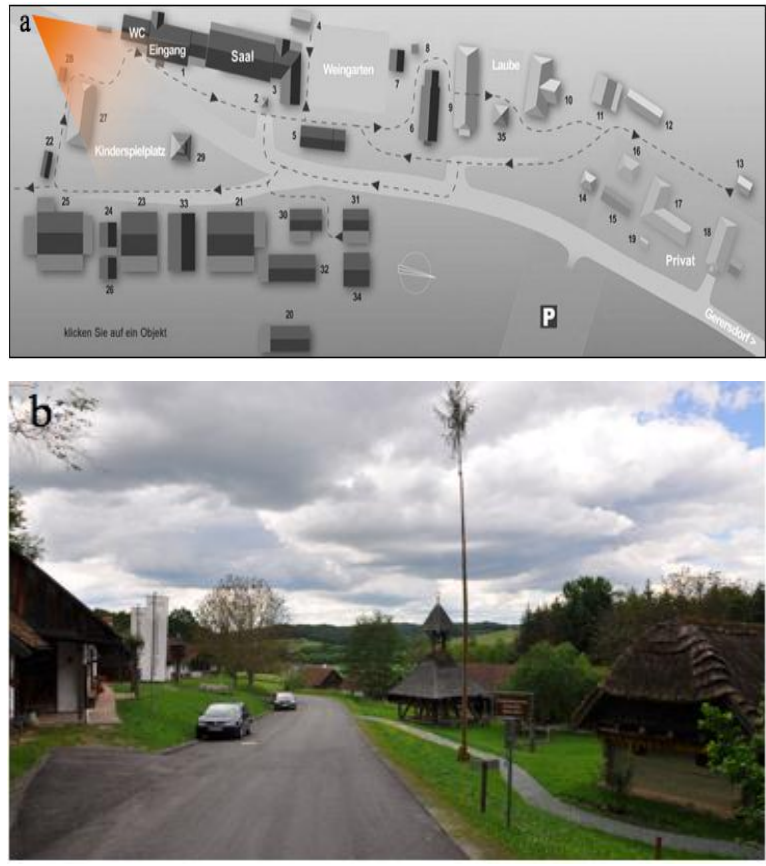

Fig. 6. (a) Gerersdorf Freilichtmuseum Map (Gerersdorf Freilichtmuseum website, 2016); (b) Gerersdorf Freilichtmuseum separated by a Hamlet road (Yusfan, 2016)

Established in 1976, Gerersdorf Freilichtmuseum as the largest outdoor museum in Burgenland consists of peasant wooden houses mainly from southern Burgenland and neighboring in western Hungary. Here, wood, clay and straw are dominantly used as indigenous materials of most buildings. As seen on the one of the collection where tree trunks were hewn manually and then plastered with mixed chopped straw clay and whitewashed.

\section{METHODOLOGY}

By reviewing described OAMs previously, this paper goes on by using qualitative methods. Based on primary data acquired from field surveys, such as photographs and some interview results, this paper extends the method that using by Paardekoper. In his recent book, Paardekooper (2012) has been examined in depth about 8 OAM in Europe and gives imagery in establishing such museum in the next future by descriptively reviewing; the locations, collections, featured buildings, attractiveness, to the management. Thus, by comparing 6 Austrian OAM above in critical descriptive ways (Attoe, 1978), this paper adopts similar parameters with logical argumentation (Groat \& Wang, 2002) so it can be identified about what are the challenges ahead in implementing a similar museum for the Indonesian. Some phenomena derived from field studies described as part of an evaluation to be considered by viewing some similarities and opportunities with Indonesian condition. The advantages and disadvantages found at each Austrian OAM tabulated so that advisable as a consideration for the opportunity of OAM concept could be appropriately implemented in Indonesia preferably.

\section{RESULTS AND DISCUSSION}

\section{Open-air museums in Austria: Its past and presents}

Reflecting on Skansen phenomenon, Austrian also trying to develop this kind of museum and marked with Stïbing in 1962 as the first. Now, after almost half a century passed, OAMs of Austria has become a reference point for the younger generation of Austrian in searching their identity. On the other hand, countless studies such as; archaeology, ethnology, anthropology to dendrology also use OAM as the starting point. Along the way, Austrian's OAM and majority OAM in the world experiencing some struggle. In the beginning, financial constraints plagued the translocation process and subsequently the maintenance process is also still haunting until nowadays.

Thus, planning on placing needs to be acquired maturely when establishing the OAM. The countryside in Austria is the right choice for showing the diversity of rural living atmosphere in Austria with its viscous agricultural life. Not surprisingly, Hurt (1978) defines OAM in Europe as the Agricultural Museum. Stübing Freilichtmuseum as the first and largest with more than $60 \mathrm{Ha}$ areas within 97 traditional houses from all over Austria are playing an important role in presenting the whole of Austrian traditional folk life images. While others collect houses from around the region or the country where it is located, such as Grossgmain Freilichtmuseum collected houses from around the Salzburg state, Kramsach Freilichtmuseum from Tyrol state, Maria Saal Freilichtmuseum from around Carinthia, Niedersulz Museumsdorf from around Nieder-Oberösterreich and Gerersdorf Freilichtmuseum from around Burgenland state.

The contour of the site in relocating the house is strictly considered (see fig. 7). Seen at Stubing, Grossgmain, especially in Kramsach which represents the condition of the Alps of Tyrol. While in Maria Saal, especially in Gerersdorf, the houses are not well arranged due to the limitedness of the site. Also seen a similar typical house form that occurs on each of these OAM. Rectangular woodblock houses with a gable roof are mostly dominant. Except in Niedersulz, where more composed of brick houses clustered on a sloping contour of the wineries because cultural influences of wine farms are the backbone of this region. Here, timber construction only used for the storage sheds and stables. The considerable comparison between these OAM could be seen in Table 1 . 


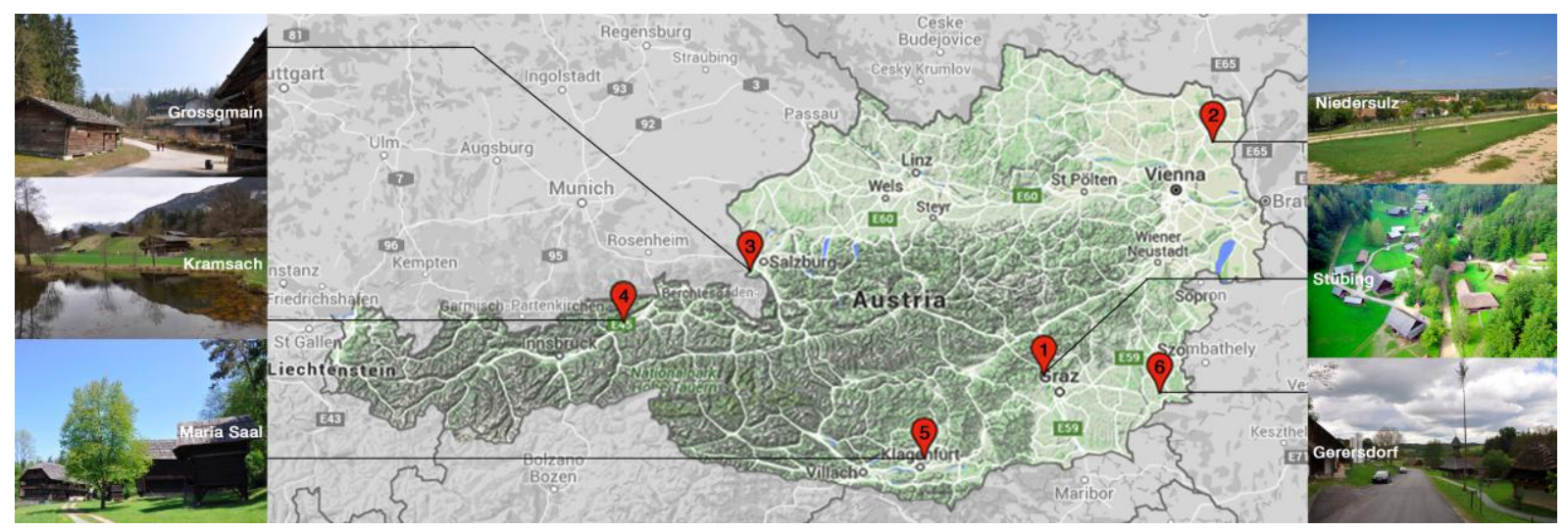

Fig. 7. The location of Open-air Vernacular Houses Museum in Austria toward its Nature (Yusfan, 2016)

Table 1. Comparison between Open-air Vernacular Houses Museums in Austria

\begin{tabular}{|c|c|c|c|c|c|c|c|c|}
\hline \multirow{2}{*}{ No. } & \multirow{2}{*}{ OAM } & \multicolumn{7}{|c|}{ Description } \\
\hline & & Site & Layout & Inside Collection & Attractive Offerings & Publications & Manage-ment & Access \\
\hline 1 & & $\begin{array}{l}\text { Located } 15 \mathrm{~km} \\
\text { north of Graz, in } \\
\text { the center of a } \\
\text { valley surrounded } \\
\text { by hills and } \\
\text { typical wilderness } \\
\text { pine forests of } \\
\text { Austria. About } 97 \\
\text { original historic } \\
\text { vernacular } \\
\text { buildings were re- } \\
\text { established here. }\end{array}$ & $\begin{array}{l}\text { Each house placed in } \\
\text { accordance with the } \\
\text { position of the states } \\
\text { in Austria on an area } \\
\text { of } 60 \text { ha. Started } \\
\text { from Burgenland, } \\
\text { Steiermark, Kärnten, } \\
\text { Oberösterreich, } \\
\text { Niederösterreich, } \\
\text { Tirol, Salzburg and } \\
\text { Vorarlberg, all } \\
\text { houses from these } \\
\text { regions were } \\
\text { arranged linearly. }\end{array}$ & $\begin{array}{l}\text { At each house, there } \\
\text { are things and tools } \\
\text { that supported the life } \\
\text { of Austrian at that } \\
\text { time such as farm } \\
\text { tools and other } \\
\text { household. In the } \\
\text { entrance area, there is } \\
\text { an exhibition building } \\
\text { contains history and } \\
\text { civilization of } \\
\text { Austrian as well as } \\
\text { show some houses } \\
\text { miniature and } \\
\text { commonly used } \\
\text { material of the house } \\
\text { in detail. }\end{array}$ & $\begin{array}{l}\text { It will take you to the } \\
\text { original farmsteads } \\
\text { from } 8 \text { states of Austria } \\
\text { and arranged according } \\
\text { to the states. Walking } \\
\text { through the valley one } \\
\text { can experience and } \\
\text { compare the variety of } \\
\text { vernacular architecture } \\
\text { from the Burgenland up } \\
\text { to Vorarlberg, } \\
\text { originating from the } \\
\text { multitude of landscapes } \\
\text { as well as from the } \\
\text { historic, social and } \\
\text { political influences. } \\
\text { Baking in the historic } \\
\text { brick oven every } \\
\text { working day, observing } \\
\text { every day's work: the } \\
\text { thatching of roofs, the } \\
\text { cutting of the shingles } \\
\text { or the repairing of } \\
\text { fences, are some events } \\
\text { that occasionally held. }\end{array}$ & $\begin{array}{l}\text { Leaflets are } \\
\text { available on the } \\
\text { counter. A very } \\
\text { informative } \\
\text { website, containing } \\
\text { information about } \\
\text { the collection in } \\
\text { the museum with } \\
\text { virtual walk site. } \\
\text { There are also a } \\
\text { souvenir shop and } \\
\text { books behind the } \\
\text { ticket stand at the } \\
\text { museum portal } \\
\text { building. }\end{array}$ & $\begin{array}{l}\text { Professionally } \\
\text { Professionally } \\
\text { managed, } \\
\text { involving } \\
\text { institutions from } \\
9 \text { states in } \\
\text { Austria and fully } \\
\text { supported by the } \\
\text { Austrian Federal } \\
\text { authority. } \\
\text { Also, there is } \\
\text { cooperation with } \\
\text { universities in } \\
\text { terms of research } \\
\text { and maintenance, } \\
\text { especially for the } \\
\text { wooden structure. }\end{array}$ & $\begin{array}{l}\text { Easily accessed by } \\
\text { private } \\
\text { transportation. } \\
\text { There is also } \\
\text { public bus } \\
\text { frequently stop in. } \\
\text { While by train, the } \\
\text { museum only can } \\
\text { be accessed by } \\
\text { walk } 2,5 \mathrm{~km} \text { from } \\
\text { the nearby station. } \\
\end{array}$ \\
\hline 2 & 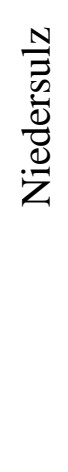 & $\begin{array}{l}\text { Located } 45 \mathrm{~km} \text { in } \\
\text { the north of } \\
\text { Vienna, the } \\
\text { museum laid in } \\
\text { the sloping plains } \\
\text { vineyards of } \\
\text { Niedersulz. On } 22 \\
\text { ha, } 80 \text { buildings } \\
\text { adorn the order of } \\
\text { typical wineries } \\
\text { life of the } \\
\text { Weinviertel. }\end{array}$ & $\begin{array}{l}\text { Most houses } \\
\text { collections made of } \\
\text { bricks arranged in a } \\
\text { grid on the site with a } \\
\text { typical house plan, } \\
\text { included stable and } \\
2 \text { other outbuildings. } \\
\text { Each house has a } \\
\text { typical wooden shed } \\
\text { (Längstadel). }\end{array}$ & $\begin{array}{l}\text { All houses were } \\
\text { equipped with a } \\
\text { collection of } \\
\text { household objects. In } \\
\text { some places, there is } \\
\text { also a workshop such } \\
\text { as cross-stitch art. } \\
\text { Even, at one house } \\
\text { featured displaced } \\
\text { original wall, result } \\
\text { of a demolished house } \\
\text { along the } \\
\text { translocation process. }\end{array}$ & $\begin{array}{l}\text { The new museumportal } \\
\text { of the museum has just } \\
\text { inaugurated in } 2012 \text {. } \\
\text { With box-shaped } \\
\text { design, this building } \\
\text { becomes an attractive } \\
\text { gateway as well as a } \\
\text { new focal point for the } \\
\text { museum. In addition, } \\
\text { there is a brick-making } \\
\text { workshop sponsored by } \\
\text { a university in Austria. } \\
\text { In the center of the } \\
\text { museum, there are cafes } \\
\text { and a dance hall where } \\
\text { visitors can enjoy a } \\
\text { glass of Weinviertel } \\
\text { genuine wine. }\end{array}$ & $\begin{array}{l}\text { The website is very } \\
\text { informative in } \\
\text { giving information } \\
\text { about the museum. } \\
\text { Unfortunately, not } \\
\text { accompanied by } \\
\text { representative map. } \\
\text { The new } \\
\text { administrative } \\
\text { building quite a } \\
\text { place to gather } \\
\text { information, } \\
\text { equipped with a } \\
\text { souvenir shop and } \\
\text { bookstore. }\end{array}$ & $\begin{array}{l}\text { Professionally } \\
\text { managed as a } \\
\text { Private Limited L } \\
\text { iability Company } \\
\text { and fully } \\
\text { supported by } \\
\text { Nieder-österreich } \\
\text { state though } \\
\text { Kultur.Region.Ni } \\
\text { eder-österreich. } \\
\text { Also, there is } \\
\text { cooperation with } \\
\text { BOKU in terms } \\
\text { of joint } \\
\text { workshops in } \\
\text { making clay } \\
\text { brick. }\end{array}$ & $\begin{array}{l}\text { Easily accessed by } \\
\text { private and public } \\
\text { (bus) } \\
\text { transportation. } \\
\end{array}$ \\
\hline 3 & 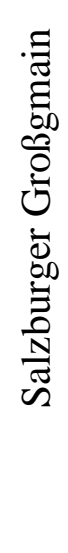 & $\begin{array}{l}\text { Located } 12 \mathrm{~km} \text { in } \\
\text { the southwest of } \\
\text { Salzburg, the } \\
\text { museum laid in } \\
\text { the middle of } \\
\text { wilderness woods } \\
\text { and hills of } \\
\text { Großgmain. }\end{array}$ & $\begin{array}{l}\text { The } 100 \text { buildings } \\
\text { were arranged on } 50 \\
\text { Ha site according to } \\
\text { the region of } \\
\text { Salzburg state. Hilly } \\
\text { site makes visitors } \\
\text { directly feel the } \\
\text { atmosphere of } \\
\text { Salzburg by } \\
\text { wandering. }\end{array}$ & $\begin{array}{l}\text { The museum collects } \\
\text { items that pertain to } \\
\text { the heritage of rural } \\
\text { farming culture and } \\
\text { daily life from the } \\
\text { beginning of the 18th } \\
\text { century to the } 1970 \text { 's. } \\
\text { Whereas the houses } \\
\text { document the } \\
\text { historical building } \\
\text { development over a } \\
\text { period of six } \\
\text { centuries, the } \\
\text { furnishing of the } \\
\text { houses, stables and } \\
\text { farm buildings serves } \\
\text { the holistic } \\
\text { representation of rural } \\
\text { living environments. }\end{array}$ & $\begin{array}{l}\text { There is a mini heritage } \\
\text { railway ride along } 1,7 \\
\text { km along the site, make } \\
\text { visitors easier to visit } \\
\text { the farther houses from } \\
\text { the entrance. } \\
\text { The location in the hills } \\
\text { is perfect for wandering } \\
\text { as well as representing } \\
\text { original condition of the } \\
\text { house and the } \\
\text { geographical condition } \\
\text { of Salzburg. } \\
\text { In some houses, } \\
\text { attached sub museum } \\
\text { which display farming } \\
\text { tools such as tractor } \\
\text { l museum, highway } \\
\text { museum, and also some } \\
\text { workshop as well as a } \\
\text { souvenir shop. }\end{array}$ & $\begin{array}{l}\text { The website is very } \\
\text { informative in } \\
\text { giving information } \\
\text { about the museum. } \\
\text { Also in the ticket } \\
\text { office, there are } \\
\text { many informative } \\
\text { books, both in } \\
\text { German and } \\
\text { English about the } \\
\text { collections in } \\
\text { detail. In the } \\
\text { website, visitor } \\
\text { could also pre- } \\
\text { explore the site } \\
\text { with virtual } \\
\text { panoramic picture } \\
\text { and predict the on- } \\
\text { site current } \\
\text { condition by live- } \\
\text { webcam }\end{array}$ & $\begin{array}{l}\text { Professionally } \\
\text { managed and } \\
\text { fully supported } \\
\text { by Salzburg state. }\end{array}$ & $\begin{array}{l}\text { Easily accessed by } \\
\text { private and public } \\
\text { (bus) } \\
\text { transportation from } \\
\text { Salzburg city. }\end{array}$ \\
\hline
\end{tabular}




\begin{tabular}{|c|c|c|c|c|c|c|c|c|}
\hline \multirow{2}{*}{ No. } & \multirow{2}{*}{ OAM } & \multicolumn{7}{|c|}{ Description } \\
\hline & & Site & Layout & Inside Collection & Attractive Offerings & Publications & Manage-ment & Access \\
\hline 4 & 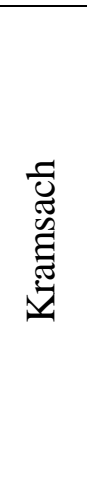 & $\begin{array}{l}\text { Situated on the } \\
\text { outskirts of } \\
\text { Kramsach hills } \\
\text { and surrounded by } \\
\text { typical wilderness } \\
\text { of Tyrol }\end{array}$ & $\begin{array}{l}\text { Each house was } \\
\text { placed in accordan- } \\
\text { ce with the original } \\
\text { contour of the land } \\
\text { where it came from. }\end{array}$ & $\begin{array}{l}\text { Things and tools that } \\
\text { support the daily life } \\
\text { of Tyrolean such as } \\
\text { farm tools and other } \\
\text { household furnishes } \\
\text { every houses. Even, in } \\
\text { some houses, equipped } \\
\text { educational programs } \\
\text { for little ones, fun and } \\
\text { educational for the } \\
\text { whole family, such as } \\
\text { how to milk a cow?, } \\
\text { how to build a log } \\
\text { cabin?, etc. }\end{array}$ & $\begin{array}{l}\text { Contoured site represents a } \\
\text { typical of the Tyrol region. } \\
\text { There are several new } \\
\text { pavilions that explain the } \\
\text { environmental, population, } \\
\text { natural resources and } \\
\text { economic conditions of } \\
\text { Tyrol. In addition, there are } \\
\text { audiovisual devices that } \\
\text { help visitor feels the } \\
\text { atmosphere/previous } \\
\text { condition of the house. One } \\
\text { house explains the process } \\
\text { for logging. And some } \\
\text { installation games available } \\
\text { on the forest path. }\end{array}$ & $\begin{array}{l}\text { The website is well } \\
\text { publicized, } \\
\text { especially in giving } \\
\text { information about all } \\
\text { events held in the } \\
\text { museum. But } \\
\text { unfortunately, } \\
\text { available in German } \\
\text { only. }\end{array}$ & $\begin{array}{l}\text { Professionally } \\
\text { managed by } \\
\text { Vereins Museum } \\
1 \text { Tiroler } \\
\text { Bauernhöfe. } \\
\end{array}$ & $\begin{array}{l}\text { Easily accessed by } \\
\text { private and public } \\
\text { (bus) transportation } \\
\text { from Brixlegg or } \\
\text { Kundl. }\end{array}$ \\
\hline 5 & 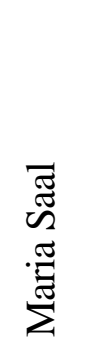 & $\begin{array}{l}\text { Located } 9 \mathrm{~km} \text { in } \\
\text { the north of } \\
\text { Klagenfurt, the } \\
\text { museum laid in } \\
\text { four terraces } 3,5 \text { ha } \\
\text { site. }\end{array}$ & $\begin{array}{l}38 \text { objects placed in } \\
\text { clusters, but very } \\
\text { close due to the lack } \\
\text { of the site. There is } \\
\text { also a wooden bridge } \\
\text { connecting main } \\
\text { museum with the sub } \\
\text { site in the west part } \\
\text { for some } \\
\text { outbuildings. }\end{array}$ & $\begin{array}{l}\text { There are collections } \\
\text { of households and } \\
\text { agricultural equipment } \\
\text { at each house, but most } \\
\text { of them are not } \\
\text { accessible. } \\
\text { b }\end{array}$ & $\begin{array}{l}\text { There is a bridge passes } \\
\text { above a side road linking the } \\
\text { main site to the sub site. In } \\
\text { addition, the site is near to } \\
\text { Maria Saal church, which is } \\
\text { quite magnificent and } \\
\text { crowded on every weekend. }\end{array}$ & $\begin{array}{l}\text { Map collection was } \\
\text { enot presented } \\
\text { representatively. } \\
\text { Book and leaflet } \\
\text { only available in } \\
\text { German. Website is } \\
\text { well managed, but } \\
\text { only available in } \\
\text { Germany and Italy, } \\
\text { and also lack of } \\
\text { detail info about the } \\
\text { collected houses. }\end{array}$ & $\begin{array}{l}\text { Unwell managed. } \\
\text { Fully supported by } \\
\text { Carinthia } \\
\text { Museum. }\end{array}$ & $\begin{array}{l}\text { Lack of clear } \\
\text { information, } \\
\text { especially access } \\
\text { from a nearby } \\
\text { station to the site. } \\
\text { By train, the } \\
\text { museum only can be } \\
\text { accessed by walk } \\
1,5 \mathrm{~km} \text { from the } \\
\text { nearby station. }\end{array}$ \\
\hline 6 & $\begin{array}{l}\frac{\pi}{0} \\
\frac{\mathscr{D}}{0} \\
\stackrel{0}{0}\end{array}$ & $\begin{array}{l}\text { Located } 8 \mathrm{~km} \text { in } \\
\text { the western of } \\
\text { Güssing, the } \\
\text { museum lay in the } \\
\text { middle of wheat } \\
\text { fields and cleaved } \\
\text { by a hamlet road. }\end{array}$ & $\begin{array}{l}\text { At the museum, } \\
\text { established } 32 \text { grid- } \\
\text { arranged collections } \\
\text { in declivous } 2 \mathrm{Ha} \\
\text { areas of the site. } \\
\text { Mostly are peasant } \\
\text { wooden houses } \\
\text { mainly from } \\
\text { southern Burgenland } \\
\text { and neighboring in } \\
\text { western Hungary. }\end{array}$ & $\begin{array}{l}\text { In some houses the } \\
\text { collection items was } \\
\text { well displayed, but in } \\
\text { some others are not, so } \\
\text { inclined as warehouse. } \\
\text { One example, in } \\
\text { Kreuzststadel from } \\
\text { Güssing (1864), found } \\
\text { both cooper and } \\
\text { shoemaker workshop. } \\
\text { But, in the middle area, } \\
\text { placed a hearse. }\end{array}$ & $\begin{array}{l}\text { Wood, clay and straw are } \\
\text { dominantly used as } \\
\text { indigenous materials of } \\
\text { some buildings in the } \\
\text { museum. There are also } \\
\text { some houses were still } \\
\text { inhabited privately by the } \\
\text { owner, so need special } \\
\text { permission to access it. }\end{array}$ & $\begin{array}{l}\text { Website is not well } \\
\text { publicized. All } \\
\text { information available } \\
\text { only in German and } \\
\text { there is nothing } \\
\text { detail info could be } \\
\text { gain from the ticket } \\
\text { office. }\end{array}$ & $\begin{array}{l}\text { Homey concept is } \\
\text { not well managed, } \\
\text { e especially for non- } \\
\text { German speaking } \\
\text { visitor. The } \\
\text { museum is } \\
\text { supported by the } \\
\text { Burgenland State. }\end{array}$ & $\begin{array}{l}\text { Easily accessed by } \\
\text { private } \\
\text { transportation only. } \\
\text { There is a regular } \\
\text { bus to Güssing, but } \\
\text { from there to the } \\
\text { museum, only } \\
\text { serves in workdays. } \\
\text { Coupled with a } 2 \\
\text { km walk from the } \\
\text { nearby bus stop to } \\
\text { the museum makes } \\
\text { a consideration to } \\
\text { visit by public way. }\end{array}$ \\
\hline
\end{tabular}

Generally, translocation process that has been done at each researched OAM carried out through several phases (abstracted from Stübing, Grossgmain and Kramsach publication). Mostly only those houses, which have lost their function at its origin, are translocated to the museum. Before transferred, held some investigation to examine first recorded related documents (sketches, photographs, etc.) of the houses to its original locations in order to assure both the authenticity and the structure, avoiding erroneous in the replacement process. Exact architectural-historical inventorying has to be done by survey of the original location before translocation, together with creating a dismantling plan and documenting all the details. Meanwhile, the existing authentic interior such as the decoration and the ornamentation also should be inventoried backed by interviews and archives to gain the social and historical story of the house. The dismantled parts of the building were being numbered in order to ease in reconstructing the building.
Before rebuilding the houses in the museum grounds, defective parts must be restored or replaced, especially the wooden part. Dendrochronological research of the structure should faultless with reference to potential modifications. Also, appropriate conservation measures have done integrally and comprehensively. Dried and rotten parts were being classified to kept or destroyed, or were collected for further research as done in Stuibing (Yusfan, 2016b).

After the reconstruction, the house equipped with all necessary households and work equipment with fully furnishings that match with the relevant timeframe. Maintenance and restoration have been kept sustained in order to maintain safety, especially at fireplaces as stoves and ovens, which is continually used for the workshop of the visitors. While, at the exterior, the planting of gardens and flowers keep nourished as attractive scenery and decorating the houses to bring visitors fused with the real atmosphere of Austrian rural houses, and also offers lots of vehicles which become peculiarities of each OAM (see fig. 8). 

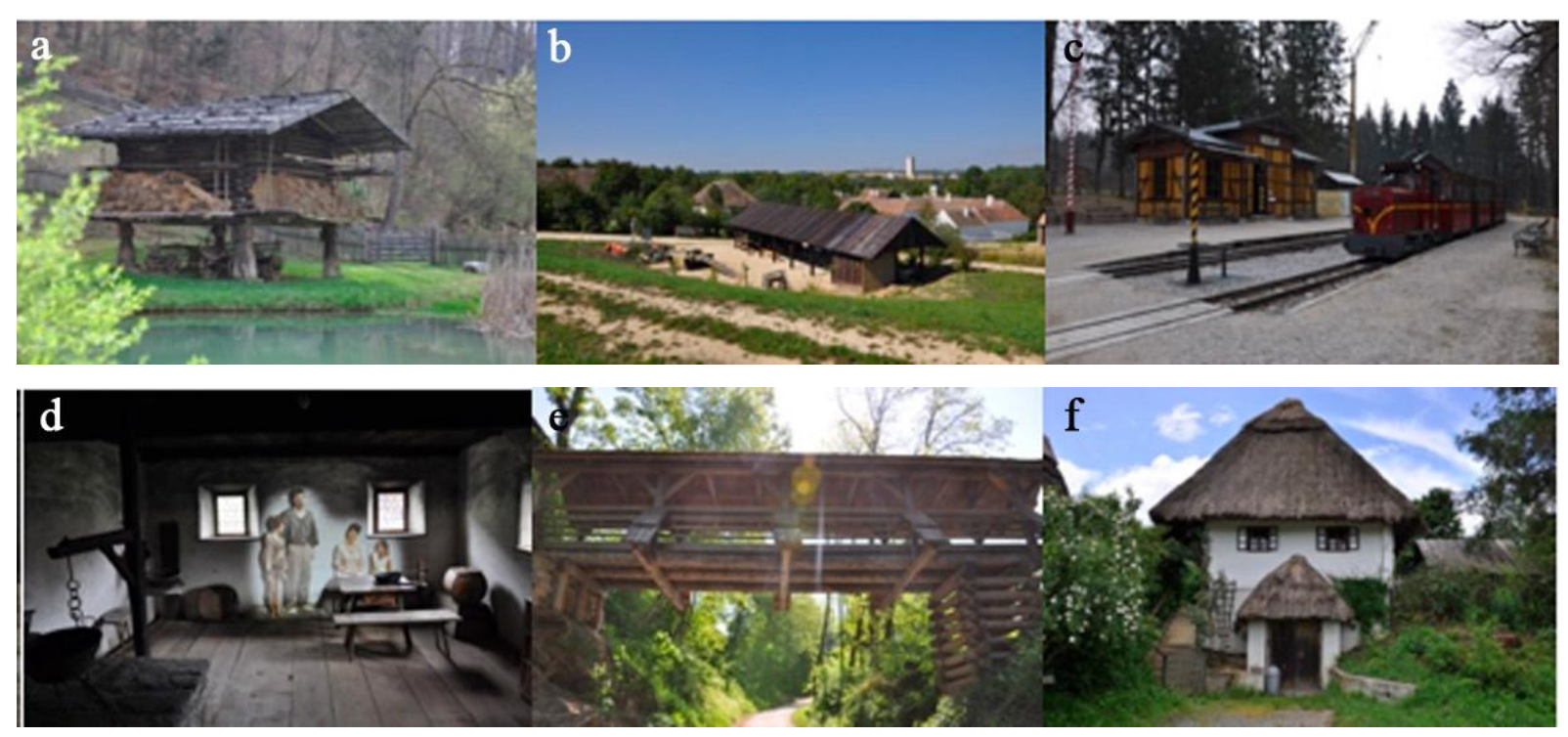

Fig. 8. Some Attractive Vehicles offered at Austrian OAMs; (a) A 1529s Barn from South Tyrol in Stübing Freilichtmuseum; (b) Workshop house for making bricks in Niedersulz museumsdorf; (c) Mini historical train to served sightseeing around Großgmain fm; (d) Virtual reality helped illustrate past life in Kramsach fm; (e) A wooden bridge attaching site terraces in Maria Saal fm; (f) One of inhabited houses in Gerersdorf fm (Source: author)

\section{Rethinking OAM in Indonesia}

In Indonesia, TMII has put the nails as one of the pioneer despite its polemic idea (Hitchcock, 2005). Regardless all of the controversy behind its establishment, opening speech of the founder has realized now, that "these newness (the house) someday will become the old". Awkwardly, if indeed TMII embodies the culture of each province, behold now, when Indonesia consists of 34 provinces. New houses were eventually forced to tuck in the frittered hind area, reflects the lack of planning (Yusran, 2016b).

On the other hand, Indonesia is still grappling to optimizing the existing museum. The national movement of love museum (Gerakan Nasional Cinta Museum) in 2010-2014 that was echoed by the government, still not enough enthused Indonesian people to visit the museum. Many reasons behind this lack of public enthusiasm for the museum, but these following reasons can be regarded as the main reason.

The first is the presentation and arrangement of artifacts or exhibitions that tend to be monotonous and boring. Collection mostly only displayed in a glass cabinet and tables with minimal information and less creative arrangement. Second, less interesting in museum as recreational preference for most of Indonesian people. The underlying reasons for this is since the museum is not an inherited culture of Indonesia (colonial cultured) (Kleiber-Schwartz, 1992; Hitchcock, 2005; Lukito, 2016). Another reason is the lack of interaction that involves visitors. Exhibitions and collections often displayed without any explanation, the guide was not always available, coupled with the absence of audio-guide supporting equipment.

Interactive collection also few exhibited, as well as elaborate activities that involve the visitors. On the other hand, lack of maintenance is also contributing in making the museum become less desirable. Oftentimes we are discouraged to visit museum because the buildings are dilapidated, perforated ceilings, stuffy atmosphere with layered dust and cobwebs decor. Creepy effect was so arise. Not surprisingly, currently some museum threatened to be closed; one of it is the oldest museum of Indonesia, Radya Pustaka Solo.

For Indonesian case, placing OAM in density area, especially in Java, needs extra consideration, especially when placed in the surroundings of a big city. It should consider the agglomeration, the availability of land and wished atmosphere to be created later. Moreover, the new tourist magnet needs to be taken into consideration also to trigger the growth and represents peculiarities of the region.

When compared with Austrian OAM, actually the house placement could vary, depending on where the origin of the building. For example, the Tyrolean houses which were collected in Kramsach. Similarly the houses around Carinthia, gathered in Maria Saal, and so forth. Only in Stübing, where comprehensive collections has been collected from almost all regions of Austria. If envisaged, in the terms of concept, it actually can be easily implemented in Indonesia. The placement of translocated houses can be collected on the nearest location of the house, or even focused on some respective islands (Yusran, 2016b). Moreover, 
even better if localized in a place that has historical value associated with the house itself.

Attractive vehicles also need to be planned maturely, avoiding boredom to visitors. Presumption 'once is enough' need to be reconsidered as a trigger in inviting families to get together to enjoy OAM later. It becomes more difficult when it only displays the collections, without any attractiveness out of the landscape even less vehicles to make the visitors play and interact with their family.

Meanwhile in Austrian OAM, often held numerous activities that arouse the desire of visitors to visit continually. But indeed, it is also influenced by the season, which with its four seasons, European has much improvisation to do more attractive outdoor activities. For example, in the spring, held a workshop to make the roof shingles while in the summer there is a workshop in making bricks. Regrettably, in Indonesia, mostly entertainment spots just simply by adding new rides, instead of some activities with visitor's involvement, especially to provide field experience and stimulating knowledge for visitors.

From the observation toward the opinion of traveling tendencies, Indonesian people more pleased to travel with family. In enjoying museums, they tend not to linger in contemplation in front of an artwork as western people do. The warning 'do not touch', 'do not step' or 'do not make noise' was not an outlawed thing in expressing their attitude, even louder with word 'please'. Self-actualization like 'selfie' and family photos are $\backslash$ compulsory when visiting a unique place. Some of these things need to get further noted in planning OAMs in Indonesia particularly, not because the museum is not an inherited culture of Indonesia, but rather on placing architecture as the container of activity in an appropriate way and making sense of place more pleasurable.

What are presented in Austrian's OAM could be as a good manual, but also it could be a pungent concern. For example, the accessibility in each of Austria OAM requires great effort, which goes into a decisive factor in creating an appropriate landscape that in accordance with its original site (contour) conditions, and indeed for the European are preferred in enjoying the site by wandering its landscape. However, if implemented in Indonesia, this concept might be less successful due to the typical Indonesian, which are very spoiled by private transportation. Thus, public transportation is also a concern, so that encourages all types of tourists can access the OAM easily later.

\section{CONCLUSION}

Austria basically could not be compared straightly with Indonesian conditions, which is geographically, Austria is landlocked, and while Indonesia is islands country. However, in principle, focusing on each area matching with its character might be as the icebreaker in implementing this plan. In case if all gathered, required some consideration to optimize the site and its potential scenery to determine flexibility in arranging collections and its atmosphere in a creatively and innovatively way, as seen in Stuibing, Salzburger Großgmain and Tiroler Kramsach Freilichtmuseum. But, no ivory that is not cracked. From the six case studies above, Maria Saal and Gerersdorf seems like fall behind among others. The size of the area looks appropriate significant in arranging the houses, so the impact in managing the scenery is less in attracting the visitors.

Indeed, overall OAM in Austria also has problems in its early establishment, especially on the issue of funding. Even, it still haunts some of them until today. However, history will not succeed without a persistent struggle. This illustration shows what has been fighting for about half a century ago by their founders, now have been relished successfully by current generation. The authenticities of these houses are show and teach us that the identity of a nation is timeless since the spirit of next generation always maintains their historical heritage.

Actually, if compared to open-air museums in other countries, the prospect of the collection that will be collected in Indonesia would be very abundant. Just look at the TB Silalahi museum in Balige, which is able to collect some of Ruma (house) and Sopo (barn) from around Lake Toba to be preserved in an ex-situ approach and at the same time making them as the first museum in Indonesia which successfully in relocating those buildings as a traditional village (Huta). Moreover, this object at once becomes a new magnet for Balige as one tourist destination around the Lake Toba. It could be a good example in arousing new paradigm of Indonesian OAM fate in the future, albeit in some hand, bureaucracy needs to be more softened.

On the other hand, continuous efforts that currently undertaken by several foundations to save customhouses and its social verve needs to be appreciated. But nor rely on it as the only approach of saving the left. The vigorous effort in preparing custom ceremonies of the reconstruction process always becomes costly burdensome. Thus, the openair museum idea can be one of the efficacious ways to moderate it because after all, the extinction is racing against time. Moreover, what has been done in the previous reconstruction process could be documented digitally, and with the newest technology could be an interactive part of the collection (shown virtually) in the OAM later. These examples clearly show that the open-air museum concept have been expanded in 
recent years by the presentation of new topics and representation forms, and how innovative ideas can be used successfully to bridge the gap between the past and the present. However, there are still many challenges to be faced by the open-air museums in the next few years. Nevertheless, the authenticity of these houses has shown and teaches us that the identity of a nation is timeless and it should be supported by the spirit of next generation to sustain the cultural heritage.

\section{ACKNOWLEDGMENT}

The author grateful to Prof. Erich Lehner, who provide prowess in guiding this research and provide endorsement so that the publication of this paper was supported by TU Wien.

\section{REFERENCES}

Attoe, W. (1978). Architecture and Critical Imagination. John Wiley \& Sons.

Direktorat Pelestarian Cagar Budaya dan Permuseuman, Kementerian Pendidikan dan Kebudayaan Republik Indonesia. (2015). Permasalahan dan Tantangan Pengembangan Museum. Available: http://kebudayaan.kemdikbud.go.id/ditpcbm/2015/05/11/permasalahan-dan-tantanganpelestarian-museum/

Groat, L. N. \& Wang, D. (2002). Architectural Research Methods. John Wiley \& Sons.

Hitchcock, M. (2005). We will know our nationbetter: Taman mini and nation building in Indonesia, Civilisations, 52-2|2005, pp.45-56.

Hurt, R. D. (1978). Agricultural Museums: A New Frontier for the Social Sciences. The History Teacher, 11(3), pp.367-375. Society for History Education, DOI: 10.2307/491627.
Kempers, A. J. B. (1971). Open-air Museum, Some General Problems. Monumentorum Tutela Ochrana Pamiatok 9, presented at the Symposium ICOMOS CSSR, pp.401-402.

Kerlogue, F. (2008). House, Form and Ethnic Identity: Tradition and Variation in House Style in Jambi Province. Indonesian Houses, 2, pp. 343344. R. Schefold, P. J. M. Nas, G. Domenig, R.Wessing. KITLV Press, Leiden.

Kleiber-Schwartz, L. (1992). From the colonial museum to the museum of the communities. Museum No. 175 Vol. XLIV, No. 3, pp.137-141. Ethnographic and Open-air Museums.

Lukito, Y. N. (2016). Exhibiting Modernity and Indonesian Vernacular Architecture: Hybrid Architecture at Pasar Gambir of Batavia, the 1931 Paris International Colonial Exhibition and Taman Mini Indonesia Indah. Springer Fachmedien Wiesbaden.

Paardekooper, R. P. (2012). The Value of an Archaeological Open-Air Museum is in Its Use: Understanding Archaeological Open-Air Museums and Their Visitors. Sidestone Press, Leiden.

Rentzhog, S. (2007). Open-Air Museums: The History and Future of A Visionary Idea. Jamtli Förlag, Sweden.

Shafernich, S. M. (1994). Open-air museums in Denmark and Sweden: A critical review. Museum Management and Curatorship, 13(1), pp.9-37, DOI: 10.1080/09647779409515384

Yusran, Y. A. (2016a). The Ebb Tide in Conserving Nusantara Architecture. Procedia Engineering, 161, pp.1343-1352. http://dx.doi.org/10.1016/j. proeng.2016.08.654.

Yusran, Y. A. (2016b). Ex-Situ Conservation on Nusantara Architecture: Implementation and Challenges (An Overview towards TMII and Stübing Freilichtmuseum). International Journal of Structural and Civil Engineering Research, 5(1), pp. 5-11. 